DOI https://doi.org/10.32837/app.v0i65.306

УДК 17.01:32:303.035.2

\author{
Е. В. Мамонтова \\ ORCID ID: https://orcid.org/0000-0003-2761-8217 \\ доктор політичних наук, професор, \\ професор кафедри політичних теорій \\ Національного університету «Одеська юридична академія» \\ Є. Ю. ПєлєВін \\ ORCID ID: https://orcid.org/0000-0001-5464-3309 \\ кандидат історичних наук, \\ старший викладач кафедри політології \\ Одеського національного політехнічного університету
}

\title{
НАУКА І ПОЛІТИКА: ЕТИЧНІ ТОЧКИ ЗІТКНЕННЯ
}

Нині, коли наша планета переживає скрутні часи, зумовлені стрімким поширенням пандемії, викликаної COVID-19, усі надії людства пов' язані з фундаментальною наукою. Від того, наскільки швидко будуть знайдені механізми протидії смертоносному вірусу та доведена ïx ефективність, залежить майбутнє кожного з нас. Без перебільшення можна сказати, що наука перетворюється на ключовий суб'єкт політики. Адже наука - це не лише сфера інтелектуальних експериментів та полігон технологічного опрацювання їх результатів, але й потужний соціальний інститут. Його місце та роль у суспільстві визначає ефективність політико-управлінських практик керівництва країни та ії конкурентоспроможність на світовій арені. Тому доречно, на нашу думку, звернутися до питання моральної відповідальності наукового співтовариства, оскільки на тлі кризи управління саме етична складова частина наукової діяльності в політико-управлінській сфері набуває першочергового значення.

Питання ролі науки в процесах управління суспільством та державою віддавна цікавили соціальних мислителів. Так, у руслі античної інтелектуальної традиції було сформовано погляд на знання як явище соціального порядку та визначено провідне місце його виробників у структурі суспільства (Піфагор, Сократ, Платон, Аристотель та ін.). У давньосхідних культурах акцентували на технологіях ефективного управління державою (Каутілья, Конфуцій, Шан Ян та ін.).

У добу Середньовіччя та Відродження ключовою задачею інтелектуалів був пошук балансу між вірою та розумом (Ф. Аквінський, Дж. Бруно, М. Кузанський, Т. Мор, М. Падуанський та ін.). У політичній філософії спроба вивести конфлікт науки та релігійної етики в конструктивне русло була здійснена М. Макіавеллі. І зовсім невипадково, що цей знаковий переворот в історії політичної думки ознаменував також початок зміни соціокультурного статусу науки та формування етосу науки, які тривали потягом XVI - поч. XVII ст.

У Нову добу, коли формування раціоналістичних підвалин просвітницького світогляду суттєво каталізувало процес інституалізації науки, питання ролі вченого в суспільному розвитку вийшло на новий рівень осмислення. На сторінках філософських трактатів обгрунтовуються та розвиваються ідеї «місіонерської ролі вченого в суспільстві» (Р. Уітлі, Б. Паскаль та ін.), поняття «моральної достовірності» (Р. Декарт, І. Кант, Г.В. Лейбніц, І. Ньютон, Б. Спіноза та ін.), положення професійної наукової етики («Десять заповідей людини науки» Л. Фейербаха).

У XVII-XIX ст., коли на зміну релігійній картині світу, яка монопольно панувала в масовій свідомості доіндустріального суспільства, приходить ідеологічний дискурс, наука розглядається як основа соціально-політичного прогресу (Ф. Бекон, П. Гольбах, М.Ф. Вольтер, Й.Г. Фіхте, А. Сен-Симон, О. Конт, К. Маркс, Ф. Енгельс та ін.). Крім того, саме завдяки інтелектуалам - ідеологам доби Просвітництва Європа та світ перейшли від революцій технічних до революцій соціальних (Дж. Локк, Ж.Ж. Руссо, Ш.-Л. Монтескье та ін.).

Згодом, із розвитком технологій та перетворенням науки на потужний соціальний інститут, коли стало зрозуміло, що раціональне знання та його матеріалізація в технічному прогресі не тільки спричинили бурхливий розвиток цивілізації, але й виступили як знаряддя 
політичного панування на міжнародний арені, встановлення контролю над масами, руйнування навколишнього середовища та соціального відчуження, роль науки як рушійної сили соціального прогресу була критично переосмислена (М. Гайдеггер, Г. Маркузе, Д. Меддоуз, Х. Ортега-і-Гассет, А. Печчеі, О. Тоффлер, Е. Фромм, М. Фуко, А. Швейцер, О. Шпенглер, К. Ясперс та ін.).

Зіткнення моральних норм наукового середовища та політичних реалій XX-XXI ст. - одна 3 центральних тем у дослідженнях, які становлять фундамент наукового етосу сучасності (Е. Агащці, Р. Гарнер, В. Енгельгардт, Т. Кун, І. Лакатос, Н. Луман, Р. Мертон, М. Полані, К. Поппер, Б. Розен, Н. Сторер, П. Фейєрабент та ін.).

Щодо етики соціально-політичних наук як окремої галузі етики науки, то ця проблематика охоплює ціле коло питань, які потребують вирішення (3. Бауман, М. Вебер, Х. Дженкинс-Сміт, Р. Мертон, М. Полані, К. Поппер, Д. Раветц та ін.). Це, зокрема, питання цінності соціального знання та його моральної достовірності, місіонерська роль вченого-гуманітарія і підвищення іiі культурно-світоглядного аспекту, соціальна відповідальність дослідника за наслідки соціальних експериментів, підвищення ролі громадянської позиції вченого в соціально-політичному процесі, науково-етичні проблеми інформаційного суспільства (інформаційні війни, маніпуляції масовою свідомістю тощо), конфлікт моральних та професійних якостей наукового працівника в дилемі «інтелігент - інтелектуал», співвідношення відповідальності та свободи, специфіка індивідуальної та колективної, внутрішньої та зовнішньої наукової етики, зв'язок принципів науки та демократії тощо. Водночас мало дослідженим є етичний вимір співвідношення науки та політики як підсистем суспільства. Найбільш наочно, на нашу думку, він відбивається в питанні соціальної відповідальності вченого, якій працює на ниві політологічних розвідок.

Мета статті полягає у спробі окреслити ареали перетинання політики та науки як явищ соціального порядку та визначенні на цій основі етичної складової частини їх взаємодії на зрізі співвідношень «політик - науковець».

Досягнення цієї мети неможливе без звернення до класичної спадщини М. Вебера, який за допомогою категорій модерного соціального знання вивів на новий методологічний рівень багатовікову дискусію навколо питань: чи має право вчений на власні політичні погляди і чи має він нести відповідальність за використання результатів своїх наукових досліджень на користь певної політичної сили? 3 його подачі сформувався один із магістральних підходів до визначення цієї дилеми. Відштовхуючись від концепту «свободи від цінностей», М. Вебер у роботі «Наука як професія та покликання» (Weber, 2012) розглядає науку як сферу, що існує поза межами конфлікту цінностей. А оскільки він $є$ перманентним та невирішуваним, наука має вийти за межі ціннісних суперечок, і все, що ӥй залишається, - лише холодне безпристрасне спостерігання за цім конфліктом.

Варіантом веберіанської трактовки співвідношення науки та політики як життєвих покликань та професійних занять $є$ визнання за наукою права мати власну цінність, яка полягає в пошуку істини (vocation). Решту цінностей вчений також може поділяти, але він не має брати участь у ціннісному дискурсі, абстрагуючись від нього та зосереджуючись суто на наукових розвідках та експериментах (profession).

Незважаючи на деякі відмінності цих двох трактовок, спільним для них є те, що вони розглядають науку та політику як два окремих світи і вимагають від вченого бути поза політикою.

Однак у реальному житті вчений не може бути вільним від цінностей, оскільки, як будьяка людина, має власні переконання, установки та уподобання як на побутовому, так і на світоглядному рівнях. Крім того, вчені, і передусім ті, що працюють у соціально-гуманітарних галузях знання, не можуть не бути залученими в політичне життя, оскільки саме політика є сферою, де перетинаються економічний, соціальний, правовий, історичний, духовний, ідеологічний та культурний простори суспільства. Тому варто підкреслити кілька моментів.

По-перше, політика, як і наука, утверджує свій критерій істинності. Однак, на відміну від науки, він має суб'єктивний характер. На шляху до змоги встановити та легалізувати контроль над ресурсами та їх розподілом політичний суб'єкт (особистість, спільнота, інститут) завжди використовує певну систему цінностей, закодовану в ідеологеми та символи. За їі допомогою 
через закріплення в масовій свідомості суб'єкт встановлює політичну владу. Там, де утверджується монополія на політичну істину, укорінюється тоталітарний політичний режим. Там, де суспільство має змогу обирати між ціннісними орієнтирами, встановлюється демократія.

По-друге, політика, як і наука, ставить собі на меті пояснення дійсності і $є$ засобом ї̈ перетворення.

По-третє, політика, як і наука, залежить від суб'єкта, який її використовує. І цим суб'єктом в обох випадках є політична влада. Її носіями можуть бути інституціолізовані та неформальні еліти, політичні лідери, але жодним чином не вчені та наукові інституції.

Актуальним стає питання взаємовідношення академічного товариства та влади. Традиційно науці в суспільстві відводиться роль продукування нових знань, які є запорукою соціального та технологічного прогресу. Невипадково в сучасній техногенній цивілізації наука та технології стають фактором конкурентоспроможності держави на світовій арені. 3 другого боку, науку можна розглядати як інструмент інтелектуалізації інших сфер соціального буття. Нині без експертного супроводження не відбувається жодна процедура прийняття рішень у підприємницьких, промислових, правничих, оборонних, освітянських, медичних та інших колах. Водночас саме в політиці загострюється етичний аспект співвідношення наукового середовища та владних інституцій.

Окреслимо кілька тенденцій взаємопроникнення науки та політики як соціальних практик.

Нині спостерігається активізація залучення науковців у політичний процес. У цього явища є прагматична та ідеалістична сторони. 3 одного боку, політика перетворює вченого на публічну персону, допомагаючи йому та його відкриттям вийти на новий рівень медійної обізнаності. 3 іншого - часто головним мотивом приходу вченого в політику є усвідомлення власної прометеївської місії.

Говорячи про взаємодію науки і політики, не можна обійти увагою і зворотний процес. Відчутною, зокрема на пострадянському просторі, є тенденція звернення багатьох політиків до наукових інтелектуальних практик. У вільний час або після закінчення політичної кар'єри політичні діячи різного рівня та статусу видають наукові монографії, захищають дисертації, читають лекції, публікують наукові статті. Статусною ознакою успішного політика стає членство в різноманітних наукових академіях (в т.ч. і недержавних). Інструментом зміцнення особистого символічного капіталу виступають вчені звання та ступені. Вони служать не тільки знаками престижу, але й дають змогу політикам легітимізувати власну точку зору як експертну.

Такий взаємообмін, на нашу думку, виявляє проблему залежності «злиденної та залежної» науки від «ресурсної та впливової» політики. Наслідками цього становища стають вихолощення ідеї месіанської (прометеївської) ролі науки, ерозія етичної інфраструктури академічного середовища, репутаційна криза всієї пострадянської науки як соціального інституту.

Водночас у таких непростих умовах найчастіше вчені в політиці реалізують свій потенціал у сфері ії експертного супроводження як радників, аналітиків, консультантів. I хоча інтелектуал на вищому рівні прийняття політичних рішень - явище вкрай рідке, нині навколо органів публічного управління, принаймні, центрального та регіонального рівнів, формується потужне консультативно-експертне середовище. Прикметою сьогодення також є заснування інтелектуальних фондів, аналітичних інституцій, консалтингових фірм навколо недержавних політичних суб'єктів - партій, громадських рухів та організацій.

У західній науковій літературі є низка класифікацій інтелектуалів, що беруть участь у політичному процесі. Так, 3. Бауман поділив їх на дві групи: «вчених-законодавців» та «вчених-перекладачів». Перші розробляють моделі суспільно-політичного порядку. Другі забезпечують взаємодію партисипантов політичного процесу (Bauman, 1991). За класифікацією, яку, спираючись на функціональний підхід, запропонував у роботі «Демократична політика та політичний аналіз» X. Дженкинс-Сміт (Jenkins-Smith, 1990), є три класи інтелектуалів у політиці. Це «адвокати ідеї» (розробляють та впроваджують політичні доктрини), «об'єктивні техніки» (реалізують соціально-політичні технології) та «адвокати клієнта» (захищають інтереси окремих політичних лідерів, груп та інститутів). На пострадянському просторі ці функціональні характеристики відповідають таким рольовим типам експертного середовища, як «ідеологи», «реформатори», «сервіс». 
Спостереження за формуванням вітчизняної культури співпраці політичного та наукового середовищ дає підстави стверджувати: активна фундація різноманітних стратегічних, економічних, соціологічних, політологічних, іміджевих центів, метою яких є обслуговування конкретних бізнес-структур, політичних партій, громадських організацій та центральних та місцевих органів влади, а також часто нетривале існування та динаміка роботи цих центрів свідчить про те, що на ринку консультативно-експертних послуг в Україні найбільш затребуваним є «сервісний» тип вченого в політиці.

Якщо в західній політичній традиції в процесі підбору експертних кадрів працює механізм прозорої конкуренції, в основу якої покладено об'єктивні рейтинги наукових здобутків, що оновлюються кожного року, то в посттоталітарних країнах наближення вченого до носіїв політичної влади зумовлюється найчастіше іншими чинниками, передусім, особистими якостями, далекими від ідеалу незаангажованого високолобого інтелектуала, який прагне не медійної обізнаності та світської суєти, а вдумливої кропіткої праці в тиші кабінету.

I тут ми знову повертаємося до головного протиріччя науки та політики як феноменів соціального порядку. Наука потребує об'єктивності, в той час як політика - це служіння груповим інтересам. Єдине, що може зробити істинний вчений у цій ситуації, - це свідомо вибрати, яким цінностям він готовий служити. Бути інтелектуально чесним, за М. Вебером, - це вміння відокремлювати власну ціннісну позицію від фактів, які подеколи можуть не подобатися (Weber, 2012, p. 349).

Сила науки - в їі раціональній методології. I саме тому наука - це простір, де через осягнення об'єктивної картини соціального світу відбувається раціоналізація політики. Завдяки науковому дискурсу, побудованому за чіткими комунікативними нормами та обмеженому етикою наукової полеміки, відбувається діалог суб'єктів - носіїв різних цінностей й політичних переконань та здійснюється акт порозуміння через вслухання в позицію іншого.

Безумовно, наука не може позбавити політику конфлікту, оскільки останній є їі сутнісною характеристику. Водночас завдяки науці конфлікт можна раціоналізувати і зробити політику більш результативною та ефективною.

Все це можливе тільки за умови додержання універсальних норм наукового етосу. Їх лаконічно сформулював у роботі «Наука і демократична соціальна структура» (1942) Р. Мертон. 3 його подання сучасні нормі наукового етосу базуються на таких принципах, як універсалізм (вимога керуватися у професійних заняттях не особистими уподобаннями, а загальними критеріями доказовості та достовірності), всезагальність (установка на солідарність, відкритість та спільний пошук істини), незацікавленість (вимога безкорисливого служіння істині), організований скептицизм (установка на доказовість, методологічну коректність, критику та самокритику наукових результатів) (Merton, 1942, pp. 115-126).

Нині предметне коло етики науки розширюється через необхідність осмислення тих норм, які мають спрямовувати не лише стосунки вчених у межах академічного співтовариства або визначати вищі пізнавальні цінності науки, а й таких, що дозволяють або забороняють певне втручання науки в природу і людину. І йдеться не тільки про науки технічного та природознавчого кола. Все це повною мірою стосується і гуманітарного знання з його соціально-інженерними підходами до управління реальністю, технологіями конструювання соціального порядку, інструментами впливу на соціальну поведінку, практиками соціальних експериментів тощо.

\section{Лimepamypa:}

Bauman Z. Legislators and interpreters: On Modernity, Post-Modernity and Intellectuals. N.Y.: Polity; New Ed edition, 1991. 224 p.

Jenkins-Smith H. S. Democratic politics and policy analysis. California, Brooks/Cole Publishing; 1st edition, 1990. 248 p.

Merton, R.K. Science and technology in a democratic order. Journal of Legal and Political Sociology. 1942. \# 1. Pp. 115-126.

Weber M. (2012[1919]) Science as a profession and vocation. In: Whimster, S., Bruun, H.H. (eds) Collected Methodological Writings. London \& New York: Routledge. Pp. 335-353. 


\section{References}

Bauman, Z. (1991). Legislators and interpreters: On Modernity, Post-Modernity and Intellectuals. N.Y.: Polity; New Ed edition. 224 p.

Jenkins-Smith, H.S. (1990). Democratic politics and policy analysis. California, Brooks/Cole Publishing; 1st edition. 248 p.

Merton, R.K. (1942). Science and technology in a democratic order. Journal of Legal and Political Sociology, 1, 115-126.

Weber, M. (2012[1919]) Science as a profession and vocation. In: Whimster, S., Bruun, H.H. (eds) Collected Methodological Writings. London \& New York: Routledge, 335-353.

\section{Анотація}

Мамонтова Е. В., ПєлєВін Є. Ю. Наука і політика: етичні точки зіткнення. - Стаття.

У статті розглянуто проблему ролі науки в процесах управління суспільством та державою. Аналізуються теоретичні підходи до осмислення науки як рушійної сили соціального прогресу. Висвітлено етичний аспект співвідношення науки та політики як підсистем суспільства. Показано, що однією $з$ центральних тем у дослідженнях, які становлять фундамент наукового етосу сучасності, є зіткнення моральних норм наукового середовища та політичних реалій XX-XXI ст. Окреслено шкалу питань етики соціально-політичних наук як окремої галузі етики науки від питання цінності соціального знання та його моральної достовірності до зв' язку принципів науки та демократії. Визначено ареал перетинання політики та науки як явищ соціального порядку та розкрито на цій основі етичну специфіку їх взаємодії на зрізі співвідношень «політик - науковець». Аналізується позиція М. Вебера щодо трактування співвідношення науки та політики як життєвих покликань та професійних занять. Доведено неможливість автономного існування науки і політики, оскільки в реальному житті вчений-гуманітарій не може бути вільним від цінностей, а політика є сферою, де перетинаються економічний, соціальний, правовий, історичний, духовний, ідеологічний та культурний простори. Показано, що політика, як і наука, утверджує свій критерій істинності, ставить собі на меті пояснення дійсності і є засобом ії перетворення, залежить від суб'єкта, який ії використовує. І цим суб'єктом в обох випадках є політична влада. Висвітлено питання взаємовідношення наукового товариства та влади. Окреслено магістральні тенденції взаємопроникнення науки та політики як соціальних практик: активізація залучення науковців у політичний процес та звернення багатьох політиків до наукових інтелектуальних практик. Показано, що найчастіше вчені в політиці реалізують свій потенціал у сфері ії експертного супроводження як радники, аналітики, консультанти. Запропоновано класифікацію експертів, що беруть участь у політичному процесі: «ідеологи», «реформатори» та «сервіс». Досліджено специфіку формування вітчизняної культури співпраці політики та науки. Показано, що на українському ринку консультативно-експертних послуг домінує «сервісний» тип вченого в політиці. Робиться висновок, що наука з огляду на ії раціональну методологію є простором, де відбувається раціоналізація політики. I хоча наука не може позбавити політику конфлікту, оскільки останній є ії сутнісною характеристикою, саме завдяки науці конфлікт можна раціоналізувати і зробити політику більш результативною та ефективною.

Ключові слова: наука, політика, етика, етос науки, цінності, експерт.

\section{Summary}

Mamontova E. V., Pelevin I. Yu. Science and politics: ethical points of contact. - Article.

The article considers the problem of the role of science in the processes of governing society and the state. Theoretical approaches to comprehend science as a driving force of social progress are analyzed. The ethical aspect of the relationship between science and politics as subsystems of society is highlighted. It is shown that one of the central themes in research, which is the foundation of the scientific ethos of modernity, is the collision of moral norms of the scientific environment and political realities of the XX-XXI centuries. Depending on the value of social knowledge and its moral authenticity from the connection of the principles of science and democracy, special problems of ethics of socio-political sciences as a separate branch of ethics of science are formulated. The points of intersection of politics and science as phenomena of social reality are determined. On this basis, the ethical specifics of their interaction are revealed on the example of the relationship "politician - scientist". M. Weber's position on the interpretation of the relationship between science and politics as life vocations and professional occupations is analyzed. The impossibility of autonomous existence of science and politics is proved, because in real life a scientist-humanist cannot be free from values, and politics is a sphere where economic, social, legal, historical, spiritual, ideological and cultural spaces intersect. It is shown that politics, like science, asserts its criterion of truth; aims to explain reality and is a means of its transformation; depends on the entity using it. And this subject, in both cases, is political authority. The problem of the interaction between the scientific community and the government is specified. The main tendencies of interpenetration 
of science and politics are outlined: intensification of involvement of scientists in the political process and appeal of many politicians to scientific-expert practices. It is shown that most often scientists in politics realize their potential in the field of its expert support as advisers, analysts, consultants. The classification of experts involved in the political process is proposed: "ideologists", "reformers" and "service". The specifics of the formation of the national culture of policy cooperation are studied. It is shown that the Ukrainian market of consulting and expert services is dominated by the "service" type of scientist in politics. It is concluded that science, due to its rational methodology, is a space where policy is rationalizing. Although science cannot rid politics of conflict, the latter is its essential characteristic, but it is through science that conflict can be rationalized and policy made more effective and efficient.

Key words: science, politics, ethics, ethos of science, values, expert. 